\title{
HMGA2/ALDH2 Fusion Protein
}

National Cancer Institute

\section{Source}

National Cancer Institute. HMGA2/ALDH2 Fusion Protein. NCI Thesaurus. Code C99429.

A fusion protein consisting of the amino acids encoded by exons 1-3 of the HGMA2 gene and the last 10 amino acids encoded by the ALDH2 gene. 